\title{
Psycholinguistic Characteristics of Secondary Predication in Determining the Construction of a Peculiar Picture of the World of a Reader
}

\section{Психолінгвістичні характеристики вторинної предикації в детермінації побудови своєрідної картини світу у читача}

Nataliya Mykhalchuk

Dr. in Psychology, Professor, Head of the Department of

Practice of English

\section{Наталія Михальчук}

доктор психологічних наук, професор, завідувач кафедри практики англійської мови

E-mail: natasha1273@ukr.net orcid.org/0000-0003-0492-9450

Researcher ID: A-9440-2019

Ernest Ivashkevych

Translator, Postgraduate student
Ернест Івашкевич перекладач, здобувач

E-mail: erikguetta@mail.ru orcid.org/0000-0001-7219-1086

Researcher ID: F-3865-2019

Rivne State University

of the Humanities

$\triangle 12$, Stepan Bandera Str., Rivne,

Ukraine, 33000
Рівненський держсавний гуманітарний університет

$\triangle$ вул. Степана Бандери, 12, м. Рівне, Україна, 33000

Original manuscript received September 20, 2018

Revised manuscript accepted January 28, 2019 


\section{ABSTRACT}

The article deals with the analysis of psycholinguistic characteristics of explication of secondary predication, which are considered as dominant determinants of constructing a peculiar picture of the world of the reader. It is noted that in the scientific literature predication is categorized as a category that facilitates the constitution of a sentence in the form of a minimal communicative unit, which helps to establish the identity of the content of the sentence and the content of the reality which is surrounding us. It was determined that predication is: a) a category that contains signs of time, modality and personalization; b) a category that is essentially quasi-communicative, that is one that manifests itself in the attitudes of the opposition to themes and rams; c) a category that contains signs of time and modality.

In this article the novel of Frederick Forsyth "The Odessa file» was analyzed (according to the structures of secondary predication). This analysis suggests that the largest number of secondary predication structures are components of predication structures: 2137 cases, representing 51.38\% of the total (4159 of all structures of secondary predication). This group includes the structures of secondary predication of all five types, but the most frequent are the structures of secondary predication, where the secondary predication is expressed by the adjective: in $35.47 \%$. In addition, it should be noted that the structures of secondary predication with the infinitive are the most frequent of all types of structures of secondary predication and make up $34.82 \%$ of the total sample size, that is, almost the third part from all amount of cases. The structures of secondary predication, that are Participle II and the structures of it modification, make up 30.89\% of the total. However, in the novel of Frederick Forsyth "The Odessa file" also there are the structures of the secondary predication of all five types. Cases when the structures of secondary predication act as components of the modification structures are the least frequent (only $39.07 \%$ of the total), however, this group also includes the structures of secondary predication of all types.

It was clarified the concept of secondary predication. We believe that secondary predication is the amplification of features of the sentence, which amplifies the meaning of the sentence to the reality that is surrounding us, thus these structures are facilitating, building the image of the world or a peculiar picture of the world of a reader, the picture which, in turn, will determine the mental scripts, frames and images of this man in the future.

Key words: secondary predication, the picture of the world of a reader, communicative unit, time, modality, personalization, quasi-communicative unit, modification structures.

\section{Introduction}

In the most contemporary philological researchers it has been repeatedly noted that the notion of predication is not universally accepted so to speak of a consistent definition. Most scholars are of the opinion 
that predication is a mandatory feature of the sentence, which correlates the content of the sentence with a reality (Harris, 1970). Predictability in the psycholinguistic literature is characterized as: a) a structural feature (Isaeva \& Patrusheva, 1990); b) essential, basic feature of any sentence or statement as a speech frame (Morokhovskaya, 1984); c) a sign of a particular type, which is explicated, first of all, through the form of the verb, which, in turn, is characterized by specific categories of time, a person and a method of explication (Karamysheva, 2002).

Some linguists categorize predication as a category that facilitates the constitution of a sentence in the form of a minimal communicative unit, which helps to establish the identity of the content of the sentence and the content of the reality which is surrounding us. For I.D. Karamysheva (Karamysheva, 2002) predication is: a) a category that contains signs of time, modality and personalization; b) a category that is essentially quasi-communicative, that is one that manifests itself in the attitudes of the opposition to themes and rams; c) a category that contains signs of time and modality.

However, despite the analysis of different psycholinguistic researches, the relation between predictability and modality is still a controversial issue. Yes, there is an opinion that modality is a category that predicts so called predictability. Then understanding the predication as a category that generates the sentence as a whole, or as signs of referring the content of the text to a real reality will correspond to a purely structural definition of the category of modality. Although it should be noted that the latter is much wider than, for example, the morphological category of the method of the verb, since modality is realized not only by verbal forms of the predicate (so-called primary modality, which determines the correlation of the content of the statement with the situational conditions of the reality which is surrounding us), but also through the insertion elements, speech inclusions, etc. (this refers to so-called secondary modality, which expresses the attitude of the speaker to the content of the statement) (Lange, Messerschmidt \& Boye, 2018).

Also in psycholinguistic articles predication is seen as a syntactic modality, leading to the semantics of the relation of denotate to the reality which is surrounding us; a special quasi-communicative property of a sentence that implements its qualitative certainty and, according 
to this, is not such as is characteristic of another, more truncated by structure, units of language (Rosenbaum, 1967).

In contemporary psycholinguistic researchers, secondary predication is studied:

1) in the paradigm of comparison with the primary predicate: secondary predication (some researchers, for example, Yu.S. Stepanov (Stepanov, 1981) use the term predicative), is such a type of connection of words and phrases within the sentence, which does not create a completely new sentence, but aims to establish a sign additionally, to underline property or certain relationship between the phenomena that displayed objective reality; thus the primary predication is the type of predicative communication that forms the sentence;

2) as a part of theories and concepts that relate to predicative constructions, their meanings and peculiarities of construction. In the paradigm of these conceptual representations, it becomes clear that the secondary predication occurs when the verbal element of the predicative design is expressed by non-individual (unpredictable) form of the verb that can not explicate modality and, as a result, it is grammatically consistent with the noun-element of a certain grammatical construction. Consequently, predicate designs are not distinguished by their structural autonomy; they are always a part of the structure of a certain sentence, forming secondary predicate bonds (Javan \& Ghonsody, 2018).

It is also important that this direction of predicative phrases is traditionally recognized by constructs of secondary predication or by secondary predicative constructions. As a result, the term «secondary predication» by the scientist E.Ya. Morokhovskaya (Morokhovskaya, 1984) considers it rather unsuccessful, because, in her opinion, it does not reflect the nature of the unit as it stands. On the profound conviction of the scientist, the term "secondary predication» is even somewhat that oriented philologists improperly. After all, quite often the units of so-called secondary predication pass the predication structures in general, which has a primary meaning, that is, they contain a fair amount of semantic load, for example: «We would expect them to stand for themselves». Therefore, in the opinion of E.Ya. Morokhovskaya (Morokhovskaya, 1984), since the predicate can represent both finite and non-finite verbs, it is necessary to distinguish between finite and non-finite predication; 
3) in the paradigm studying the syntax of a simple sentence (Stepanov, 1981).

Consequently, predicate can be regarded as a phenomenon intended to refer the content of a certain statement to the reality, and as a result, predicate is static. Predication serves to achieve a connection between concepts, it provides a reflection of the nominative content of the statement and is characterized by great dynamism. The structural means of expressing predication can be a binary structure of the subject-predicate word combinations. In this case, the primary predication takes place, and the form of its expression is the structure of the primary predication. However, the subject and the predicate can be explicated in the deep structure of the statement and have so-called superficial expression. Such a special type of connection of concepts is called secondary predication, and the structural means of its expression are structures of secondary predication. Secondary predication is a predication of the so-called «second» plan, which is possible only with the actualization of the primary predication, and, as a result, dependent on the latter. Primary predication is a type of connection between words and phrases which form sentences. Secondary predication does not serve to form or formulate a sentence, but it establishes some additional attributes or relationships between phenomena and subjects of objective reality. Therefore, the structures of secondary predication in the formal plane are subordinated to the primary predication and can not function of their own, independent status. However, secondary predication by its semantic load is identical to the structures of primary predication.

Having investigated the semantics of syntactical constructions expressing the estimation of identification, it is assumed that semipolynomial verbs «appear», «happen», «chance», «turn out», «prove» are included into the micro-system of subjective evaluation of identification. In their semantics, these verbs approach the modal words of probability («maybe», «perhaps», «probably», etc.). However, unlike the latter, they contain the lexical meaning of «look», «surrender», «appear» and, as a consequence, express the probability that it is issued. In this meaning, they form some combinations with the infinitive of various full-length verbs, which in their syntactic role are similar in terms according to modal-verb constructions (Isaeva \& Patrusheva, 1990). For example:

- Had Hoffmann been watching, he would have been forced to give Miller full marks for cheek (Forsyth, 1973). 
- If there had ever been a trial, or even an arrest, of anyone who had been guilty of crimes in Riga, it would have been here in Hamburg? (Forsyth, 1973)

Similar is the opinion of scientists, when given examples as structured sentences refer to the group «Simple and Complex sentences with modal predicates».

However, scholars have repeatedly noted that in constructions with the verbs «seem», «appear» and others content of the object of evaluation relates, as a rule, to two alternative situations (Stepanov, 1981):

- «The point surely is», said the head of the Shabak at last, «that those rockets must never fly. If we cannot prevent them from making warheads, we have to prevent the warheads from ever taking off» (Forsyth, 1973).

The characteristics of subjective evaluation are either objective evidence of the referent, or signs that are conceived by the communicant and have no objective prerequisites that explicate it in the content's frames of the referent (Harris, 1970). The view that some information is largely conceived by a communicant is confirmed by the fact that the sentence is presented as the example contains two proposals. The peculiarity of such sentences is that at the surface level the subject of only one sentence is expressed, for example: «...that those racks must never fly» (Forsyth, 1973), and the subject of the second one is available implicitly: «The point surely is» (Forsyth, 1973). Therefore, we believe that such sentences should be considered as sentences containing a complex subject («...said the head of the Shabak at last» (Forsyth, 1973)), rather than a compilation of predicates.

In the researchers (Isaeva \& Patrusheva, 1990; Rosenbaum, 1967; Stepanov, 1981) deal with semantic explication of a certain sentence in the transformational Generative Grammar, it was stated that one of the immediate tasks of substantiating the deep structure of syntactic constructions was the problem of solving syntactic homonymy:

(1) John seems to know the answer «Здається, Джон знає відповідь»;

(2) John wants to know the answer «Джон хоче знати відповідь».

Thus, I.D. Karamysheva (Karamysheva, 2002) notes that the verbs «seem» and «want» at the surface level are found in identical structures. However, there are significant differences between them: 
(a) questions of such type as «What does John want?» are possible, but the questions as «What does John seem?» are impossible;

(b) «split up» (cleft) sentences are possible in word combinations as with «want»: «What John wants is to know the answer», they are impossible with «seem»: «What John seems is to know the answer»;

(c) after «want» we can use the infinitive with the subject: «John wants Harry to win the prize»; after «seem» we can't: «John seems Harry to win the prize»;

(d) the verb «seem» is allowed in the surface structure «There...» as a simple subject, but the verb «want» isn't allowed: «There seems to be a man in the garden», but not «There wants to be a man in the garden».

All these differences I.D. Karamysheva (Karamysheva, 2002) explains by the differences in the depth structure of (1) and (2) sentences. The scientist notes that the verb «want» belongs to the category of verbs with so called «object immersion», and the verb «seem» belongs to the category of verbs with «subjective immersion» (Fig. 1 and 2):

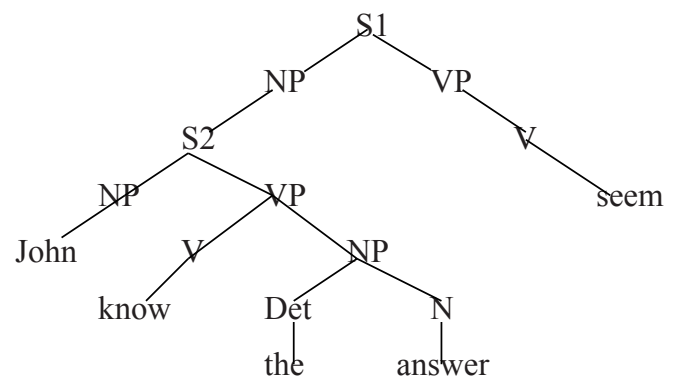

Fig. 1. The structure of the example (1)

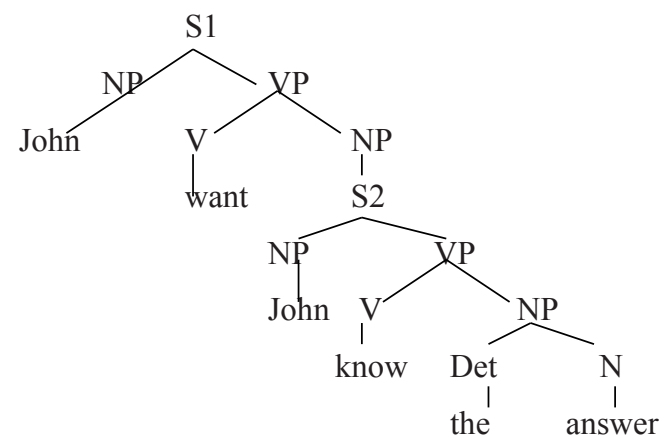

Fig. 2. The structure of the example (2) 
Also I.D. Karamysheva notes that the embedded sentence S2 is included into a structure of verbal phrase of the main (matrix) sentence S1 in Fig. 2. In Fig. 1 the included sentence S2 is a part of a noun-sentence S1 (Karamysheva, 2002). This presentation of the sentence in conjunction with «seem», that confirms the fact that these sentences should be characterized as containing a Complex Subject, rather than a Complex Predicate.

\section{Methods and methodical instrumentation of the research}

The following methods were used to study the empirical results of the research: a descriptive method - in order to distinguish units that denote the structures of secondary predication; the method of distributive analysis - for dividing the selected units (secondary segmentation) into word forms for the purpose of their analysis, classification and interpretation for the use of the data obtained during the formal description of the structures of secondary predication; the method of syntactic transformation - to identify those signs of structures of secondary predication that are not explicitly present in the analyzed novel. In addition, the elements of quantitative analysis were used in the research to determine the frequency of models of the investigated structures and their components and the characteristics of the correlation between the obtained indicators.

\section{The results of the research and their discussion}

Thus, we'll describe the structural peculiarities of secondary predication and give a complete list of means of expression of secondary predication from the novel of Frederick Forsyth «The Odessa file». First of all, we'll present the differential signs of the object-predicative structure. The most well studied among the structures of secondary predication are the object-predicate structures, known in normative grammar as Complex Object. There are several interpretations of this structure:

1. At first, the Complex Object is considered as a three-component structure with so-called «object-predicative» term (Chafe, 1967). 
It is well known that Complex Object structures are complex verb conjugations with the object and qualification applications. To this type of phrases constructs are included, for example, to see one smile, to make him weep, etc., where the verb as the base word belongs to so-called «closed» vocabulary. The first application - the object - in this phrase can be represented by a noun, a substantive pronoun or a substantive (less often a pronoun) phrase. The second application, qualifying, may be expressed as part of a language, a phrase or a form of the word, which can be used as a qualifying supplement in a simple verbal combination. This may be, for example, a noun or substantive phrases, an adjective or adjective phrases, etc.

Here are the examples of a noun or a substantive phrase from the novel of Frederick Forsyth «The Odessa file»:

- «The steely November light washed across the room, making him blink» (Forsyth, 1973).

- «He had recently finished a well-received series on the steady infiltration of Austrian, Parisian, and Italian gangsters into the gold mine of the Reeperbahn, Hamburg's half-mile of nightclubs, brothels, and vice, and had not yet been paid for it. the thought he might contact the magazine to which he had sold the series, then decided against it» (Forsyth, 1973).

- «At the end of her turn, when the applause started, the girl had dropped the bored poise of the professional dancer, bobbed a shy, halfembarrassed little bow to the audience, and given a big sloppy grin like a half trained bird dog which against all the betting has just brought back a downed partridge» (Forsyth, 1973).

- «On the outside of the front cover a square of white paper had been pasted, and over it a larger square of cellophane to keep it clean» (Forsyth, 1973).

Here are the examples of adjective or adjective phrases from the novel of Frederick Forsyth «The Odessa file»:

- «She stripped to the music with the habitual supposedly sensual gestures, her face set in the usual bedroom pout of strippers» (Forsyth, 1973).

- «He could not make them personal» (Forsyth, 1973).

- «The contents consisted of a hundred and fifty pages of typewritten script, apparently banged out on an old machine, for some 
of the letters were above the line, others below it, and some either distorted or faint» (Forsyth, 1973).

- «I hated the people, and the trees and the rocks, for they had conspired against me and made me suffer» (Forsyth, 1973).

- ««Well, what have we here?» he cried, pointing to her with his quirt to draw the attention of his comrades in the center of the square guarding the hundred already chosen» (Forsyth, 1973).

In the word-combinations of such a type to see him run, both dependent words - him and run - are complements with the verb (Karamysheva, 2002).

2. In the scientific literature there are distinguished two concepts - the Complex Object and the Objective Predicative (Stepanov, 1981). In the case of dealing with the Complex Object, the nominal part with the predicate element can form a single entity that will necessarily be object-oriented to the verb and, in its meaning, be equated to a subordinate sentence, although not in all cases it may be replaced:

You'll find it dry = You'll find that it is dry (Karamysheva, 2002).
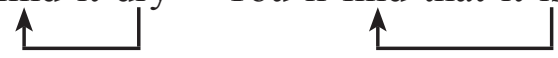

The first case is explicated in the sentences from the text:

- «Will you be quiet! You'll get us all killed» (Forsyth, 1973).

- «This at least was the argument I repeated to myself, but was it the real reason?» (Forsyth, 1973).

- «From among the crowded stretchers in the snow of the quay I heard a voice shout in the Hamburg dialect, 'Good for you, Captain. You tell the swine'» (Forsyth, 1973).

3. Complex Object is considered as a complex term of a sentence, or nexus (Karamysheva, 2002).

- There was an hour's delay at the Marienborn Checkpoint while he filled out the inevitable currency-declaration forms and transit visas travel though 110 miles of East Germany to West Berlin; and while the blue-uniformed customs man and the green-coated People's Police, fur-hatted against the cold, poked around in and under the Jaguar (Forsyth, 1973).

- I damn well would. I'm fed up with being pushed from pillar to post around this lousy country (Forsyth, 1973).

There are many more examples in the text with the Subject Infinitive Complex. 
1) The detective approached it and proffered his police card (Forsyth, 1973).

2) The man took the file back to the three missing sheets after copying (Forsyth, 1973).

3) He stared out of his office window and thought back to the image of SS General Glucks facing him in a Madrid hotel room more than thirty days earlier, and to the general's warning about the vital importance of maintaining at all costs the anonymity and security of the radio-factory-owner now preparing, under the code name Vulkan, the guidance systems for the Egyptian rockets (Forsyth, 1973).

4) Miller was shown into a small waiting room adorned by several Rowland Hilder prints of the Cotswolds in autumn (Forsyth, 1973).

5) Never mind, you go back to sleep if you feel like it (Forsyth, 1973).

Other examples of sentences from the novel of Frederick Forsyth «The Odessa file» with a Subject Infinitive Complex are:

- «I had nothing else to do this weekend» (Forsyth, 1973).

- «Nobody seems to know what he is doing at the moment» (Forsyth, 1973).

- ««I mean,' continued Miller as if the interruption had not occurred, "he must have been remarkable to be the first man since Jesus Christ to have risen from the dead» (Forsyth, 1973).

- ««I suppose I ought to thank you,» he said without gratitude» (Forsyth, 1973).

- ««I hope my English is good enough,» said Miller at last, when no reaction seemed to be coming from the retired prosecutor» (Forsyth, 1973).

Here is the example from the novel «The Odessa file» by Frederick Forsyth, when the structures of secondary predication are formed with the help of the undefined form of the verb (infinitive):

- «He would have telephoned her if she had a telephone, but as she had none, he had to drive out to see her» (Forsyth, 1973).

- «The seriousness with which the caller and his colleagues took the threat posed by Miller was indicated by the decision to send him a personal bodyguard the next day to act as his chauffeur and stay with him until further notice» (Forsyth, 1973).

- «Back in Nuremberg, the lawyer replaced the phone and returned to the living room» (Forsyth, 1973). 
- «Back in his chair Miller stared at him, open-mouthed» (Forsyth, 1973).

- «Any reasonably well-administered concern founded with plenty of liquidity in the early fifties could take full advantage of the staggering economic miracle of the fifties and sixties, to become in turn a large and flourishing_business» (Forsyth, 1973).

In the novel «The Odessa file» by Frederick Forsyth there are quite a lot of examples of the structures of secondary predication which are formed with the help of Participle I. Such structures are:

- «Right down the long, broad, straight highway through Altona toward the center of Hamburg, other drivers had heard the same broadcast and were pulling in to the side of the road as if driving and listening to the radio had suddenly become mutually exclusive, which in a way they had» (Forsyth, 1973).

- «Along his own side he could see the brake lights glowing on as the drivers ahead swung to the right to park at the curb and listen to the supplementary information pouring from their radios» (Forsyth, 1973).

- ««You heard it?» asked the man, bending down to the window» (Forsyth, 1973).

- «As a reporter he could imagine the chaos sweeping across the newspaper offices of the country as every staff man was called back to help put out a crash edition for the morning breakfast tables» (Forsyth, 1973).

- ««Ja, ja, ja,» he murmured with sagacity, as if he had seen it coming all along» (Forsyth, 1973).

- ««Ja, gute Nacht,» he called out of the open window, then wound it up against the sleet whipping in off the Elbe River» (Forsyth, 1973).

- «He finished his cigarette, still listening to the radio, wound down the window, and threw the stub away» (Forsyth, 1973).

- «At a touch of the button the 3.8-liter engine beneath the long sloping bonnet of the Jaguar XK $150 \mathrm{~S}$ thundered once and settled down to its habitual and comforting rumble, like an angry animal trying to get out of a cage» (Forsyth, 1973).

- ««I'm press,» said Miller, proffering his Hamburg city press card» (Forsyth, 1973). 
- «To cap the effect, the man seemed to have two pale and jagged scars running down his face, each from the temple or upper ear to the corner of the mouth» (Forsyth, 1973).

Consequently, the essence of the psycholinguistic transformation in given examples is in that when, applying the predicative rule, the psycholinguistic presentation of the secondary predicate is in the structure of secondary predication occurs in any cases, which leads to the formation of a particular predicate unit and, first of all, indicates that the sentence with these structures contain several plans (or aspects) of predication. These aspects of predication we mean the determinants of constructing a peculiar picture of the world of the reader.

So, we think that predication corresponds to the modality when it comes to referring the contents of the sentence to the surrounding reality (or - text reality). It is indisputable that modality is the basic sign of the sentence, because the sentence explains not only the message about the prerequisites of the surrounding reality, but also the attitude directly to the speaker. However, one should clearly distinguish the characteristics of modality by the following parameters: 1) modality, which is the sign of any sentence - it is about objective modality; 2) modality as the attitude of the speaker to what he/she is reported so-called subjective modality.

Also we have to emphasize that predication includes the following psychological meanings as:

- the meaning of the person: any sentence reflects whether a participant in a quasi-communicative or communicative act is described by the sentence, from the point of view of a speaker, by a listener or according to this act of communication performed by the other person. It should be necessarily noted that we call the Person a man who is a creator of the surrounding world, a person who is not only and is not so capable of his/her own creativity, but himself/herself id devoted to his/her existence, views, thoughts, dreams, and, in such a way, he/ she brings creativity to the surrounding reality. In this context, when psychologists say the phrase «the meaning of a person», this meaning refers to "the significance» of a subject, which, in our opinion, shows the speaker's anthropocentrism as a certain expression;

- the meaning of time: in any sentence it is explicated how the speaker correlates the time of the event described with a real time of the communicative act. To our mind in this context it would be more 
appropriate to tell about the value of locally-temporal bearing of the statement;

- the value of the method of providing the activity (we can say «the value of the way of presentation of a statement», thinking about the value which is wider than modality): in any sentence it is expressed how the speaker estimates the reality of the event described by him. All components of secondary predication are transmitted, as a rule, through verbal components, which contain all the grammatical features of a simple sentence. So, telling in Grammar terms, the verb turns out to be the main part of speech. At the same time, predication gives one or another additional sign to a particular subject, object or substance.

\section{Conclusions}

The analysis of the novel of Frederick Forsyth «The Odessa file» suggests that the largest number of secondary predication structures are components of predication structures: 2137 cases, representing 51.38\% of the total (4159 of all structures of secondary predication). This group includes the structures of secondary predication of all five types, but the most frequent are the structures of secondary predication, where the secondary predication is expressed by the adjective: in $35.47 \%$. In addition, it should be noted that the structures of secondary predication with the infinitive are the most frequent of all types of structures of secondary predication and make up $34.82 \%$ of the total sample size, that is, almost the third part from all amount of cases. The structures of secondary predication, that are Participle II and the structures of it modification, make up $30.89 \%$ of the total. However, in the novel of Frederick Forsyth «The Odessa file» also there are the structures of the secondary predication of all five types. Cases when the structures of secondary predication act as components of the modification structures are the least frequent (only $39.07 \%$ of the total), however, this group also includes the structures of secondary predication of all types.

Also we have clarified the concept of secondary predication. We believe that secondary predication is the amplification of features of the sentence, which amplifies the meaning of the sentence to the reality that is surrounding us, thus these structures are facilitating, building the image of the world or a peculiar picture of the world of a reader, the 
picture which, in turn, will determine the mental scripts, frames and images of this man in the future.

\section{References}

Isaeva, G.T., \& Patrusheva, Zh.L. (1990). Polipredykatyvne uskladnennia rechennia strukturamy vtorynnoi predykatsii [Polipredicative complication of sentences with structures of secondary predication]. Inozemna filolohiia - Foreign philology, 97, 10-16 [in Ukrainian].

Chafe, W.L. (1967). Language as symbolization. Language, 43, 57-91. https://doi. org $/ 10.2307 / 411385$

Forsyth, F. (1973). The Odessa file. L.: Book club.

Harris, Z.S. (1970). Papers in structural and transformational linguistics. Dordrecht: D. Reidel Publishing Co. https://doi.org/10.1007/978-94-017-6059-1

Javan, S.S., \& Ghonsody, B. (2018). Learning a Foreign Language: a new path to enhancement of Cognitive functions. Journal of Psycholinguistic Research, 47(1), 125-138. https://doi.org/10.1007/s10936-017-9518-7

Karamysheva, I.D. (2002). Struktury vtorynnoi predykatsii u anhliiskii movi: do pytannia klasyfikatsii [Structures of secondary predication in the English language: to the question of classification]. Visnyk Natsionalnoho universytetu "Lvivska politekhnika». Problemy linhvistyky naukovo-tekhnichnoho $i$ khudozhnoho tekstu ta pytannia linhvometodyky - Bulletin of the National University «Lviv Polytechnic». Problems of linguistics of scientific, technical and artistic text and the issue of linguistic methods, 465, 82-86 [in Ukrainian].

Lange, V.M., Messerschmidt, M., \& Boye, K. (2018). Contrasting Grammatical and Lexical Determiners. Journal of Psycholinguistic Research, 47(30), 467-482. https://doi.org/10.1007/s10936-017-9531-x

Morokhovskaya, Eu.Ya. (1984). Osnovy teoreticheskoj grammatiki anglijskogo yazyka [Fundamentals of Theoretical Grammar of the English language]. Kiyv: High school [in Russian].

Rosenbaum, P.S. (1967). The Grammar of English predicate complement constructions. Cambridge (Mass.): MIT Press.

Stepanov, Yu.S. (1981). Imena. Predikaty. Predlozheniya. Semiologicheskaya grammatika [Names. Predicates. Suggestions. Semiologic Grammar]. Moscow: Science [in Russian].

\section{АНОТАЦІЯ}

Статтю присвячено аналізу психолінгвістичних характеристик експлікачії вторинної предикації, які вважаються своєрідними детермінантами побудови своєрідної картини світу у читача. Зазначено, що в науковій літературі предикативність розглядається як категорія, що фасилітує конституювання речення у вигляді мінімальної комунікативної одиниці, що сприяє встановленню ідентичності змісту речення та змісту оточуючої нас дійсності. Встановлено, що предикативність - це: а) категорія, що вміщує ознаки часу, модальності 
та персоналізації; б) категорія, що є за своєю суттю квазікомунікативною, тобто такою, що виявляє себе у відношеннях опозиції теми та реми; в) категорія, що вміщує ознаки часу й модальності.

В статті проаналізовано твір Фредеріка Форсайта "Одеський файл» на предмет структур вторинної предикації. Цей аналіз дозволяє стверджувати, що найбільща кількість структур вторинної предикації $\epsilon$ компонентами структур предикації: 2137 випадків, що становить 51,38\% від загальної кількості (4159 усіх структур вторинної предикації). До иієї групи належать структури вторинної предикації усіх п'яти типів, проте найчастотнішими $\epsilon$ структури вторинної предикації, де вторинний присудок виражено дієприкметником: 35,47\%. Крім того, слід зазначити, що структури вторинної предикації з інфінітивом є найчастотнішими зі всіх типів структур вторинної предикації і становлять 34,82\% від загальної кількості вибірки, тобто майже третину. Структури вторинної предикації, що $\epsilon$ дієприкметником II та компонентами структури модифікації, становлять 30,89\% від загальної кількості. Проте, у творі Фредеріка Форсайта «Одеський фрайл» також $\epsilon$ структури вторинної предикації усіх п'ятьох типів. Випадки, коли структури вторинної предикації виступають компонентами структури модифікації, $\epsilon$ найменш частотними (усього 39,07\% від загальної кількості), проте до иієї групи теж належать структури вторинної предикації усіх типів.

Уточнено поняття вторинної предикації. Зазначено, що предикативність $\epsilon$ обов'язковою ознакою речення, яка амплірікує зміст речення до оточуючої нас дійсності, фасилітуючи, таким чином, вибудовування у читача образу світу або своєрідної картини світу, яка, в свою чергу, визначатиме мисленнєві скрипти, фрейми та образи даної людини в майбутньому.

Ключові слова: вторинна предикація, картина світу читача, комунікативна одиниця, час, модальність, персоналізація, квазікомунікативна одиниця, структури модифікації.

\section{Михальчук Наталья, Ивашкевич Эрнест. Психолингвистические характеристики вторичной предикации в детерминации формирования своеобразной картины мира у читателя}

\section{АННОТАЦИЯ}

Статья посвящена анализу психолингвистических характеристик экспликации вторичной предикации, которые считаются своеобразными детерминантами формирования своеобразной картины мира у читателя. Отмечено, что в научной литературе предикативность рассматривается как категория, которая фасилитирует конституирование предложения в виде минимальной коммуникативной единицы, способствует установлению идентичности содержания предложения содержанию окружающей нас действительности. Установлено, что предикативность - это: а) категория, которая содержит признаки времени, модальности и персонализации; б) категория, которая 
является по своей сути квазикоммуникативной, то есть такой, что проявляется в отношениях оппозиции темы и ремы; в) категория, которая содержит признаки времени и модальности.

В статье проанализировано произведение Фредерика Форсайта «Одесский файл» на предмет структур вторичной предикации. Этот анализ позволил утверждать, что наибольшее количество структур вторичной предикации являются компонентами структур предикации: 2137 случаев, что составляет 51,38\% от общего количества (всего было проанализировано 4159 структур вторичной предикации). K этой группе относятся структуры вторичной предикации всех пяти типов, однако наиболее часто употребляются такие структуры вторичной предикации, где вторичное сказуемое выражено причастием: 35,47\% случаев. Кроме того, следует отметить, что структуры вторичной предикации с инфинитивом употребляются наиболее часто (если сравнивать со всеми типами структур вторичной предикации), что составляет 34,82\% от общего количества выборки, то есть почти треть. Структуры вторичной предикации, которые являются причастием II и компонентами структуры модификации, составляют 30,89\% от общего количества. Однако, в произведении Фредерика Форсайта "Одесский файл» также употребляются структуры вторичной предикации всех пяти типов. Случаи, когда структуры вторичной предикации выступают компонентами структуры модификации, являются наименее частотными (всего 39,07\% от общего количества), однако к этой группе также относятся структуры вторичной предикации всех типов.

В статье уточнено понятие вторичной предикации. Отмечено, что предикативность является обязательным признаком предложения, она амплифицирует смысл предложения к окружающей нас действительности, и, таким образом, фасилитирует выстраивание у читателя образа мира или своеобразной картины мира, которая, в свою очередь, будет определять мыслительные скрипты, фреймы и образы данного человека в будущем.

Ключевые слова: вторичная предикация, картина мира читателя, коммуникативная единица, время, модальность, персонализация, квазикоммуникативная единица, структуры модификации. 